\title{
Lack of correlation between free erythrocyte porphyrin and serum ferritin values at birth and at 2 months of life in low birthweight infants
}

\author{
G FALDELla, R ALESSANDRONI, G P SALVIOLI, M CAPELli, M PAOLINI, \\ G MINAK, JR, AND S TIRAFERRI
}

Department of Paediatrics, University of Bologna; Laboratory Service, S Orsola Hospital, Bologna; Children's Hospital, Rimini, Italy

SUMMARY Red cell free erythrocyte porphyrin and serum ferritin determinations were performed on capillary blood specimens from 63 healthy infants weighing $2500 \mathrm{~g}$ or less at birth, during the first week of life, and, from 44 of them, again at 8-10 weeks. Free erythrocyte porphyrin values were high both at 3-7 days (mean $156 \mu \mathrm{g} / 100 \mathrm{ml} \mathrm{RBC}$ ) and at 8-10 weeks (mean $128 \mu \mathrm{g} / 100 \mathrm{ml} \mathrm{RBC}$ ). The respective serum ferritin values were also high (mean 226 and $107 \mathrm{ng} / \mathrm{ml}$ ), excluding a depletion in iron stores. In addition, no correlation was found between free erythrocyte porphyrin and serum ferritin values either at birth or at age 2 months. These findings are consistent with an earlier hypothesis that in the presence of iron stores, the rate of iron release from the stores in low birthweight infants may not be sufficient to maintain optimal erythropoiesis if the demand is accelerated.

If iron incorporation into protoporphyrin IX is blocked, porphyrin will accumulate in the red blood cells (RBC). This may be caused by lack of the substrate in iron deficiency ${ }^{1-4}$ or by an enzymatic imbalance, as in congenital erythropoietic protoporphyria, ${ }^{2}$ or can be caused by a lead overload. ${ }^{5-7}$ Even at the latent stage, free erythrocyte porphyrin (FEP) is a sensitive indicator of iron deficiency. ${ }^{4}$

The concentration of serum ferritin (SF) reflects the extent of iron stores in healthy infants as it does in states of iron deficiency or excess. ${ }^{8-10}$ For this reason, SF radioimmunoassay is useful in the evaluation of iron status. ${ }^{11} 12$

Because of their proportionately smaller iron stores at birth and the increased demands of a more rapid rate of growth, low birthweight infants are particularly susceptible to iron deficiency. ${ }^{13} 14$

The study had two purposes. Firstly, we wished to evaluate FEP concentrations at birth and at 2 months of age in low birthweight infants. Secondly, we wished to study the relationship between FEP values and iron stores, as determined by the SF assay.

\section{Patients and methods}

Sixty-three low birthweight infants were studied (group A). Their mean weight was 2140 (range
1380-2500) g. Sixteen of them (group A2) weighed $2000 \mathrm{~g}$ or less. Their mean weight was 1740 (range 1380-2000) g. The mean weight of the remaining 47 infants (group A1) was 2275 (range 2050-2500) g. All the infants remained free of infection during the study.

Capillary blood was obtained by heel prick from every infant during the first week (but not before day 3), and again, from 44 of the 63 infants, at age 8-10 weeks.

Each infant was given iron supplementation. ${ }^{15}$ For the 44 retested infants, iron supplements were begun after the second haematological examination so as not to prejudice the results, and for the remaining 19 infants supplements were started at about age 2 months. Heel pricks were taken from 21 healthy term infants at 3-7 days of life (control group). Their mean weight was 3330 (range 2600-4000) g.

Haemoglobin concentration and RBC indices were performed on a Model S Coulter Counter. The reticulocyte count was determined microscopically. FEP was determined fluorometrically as described by Piomelli. ${ }^{16}$ SF was determined by radioimmunoassay (Ramko Lab. Inc., Houston, Texas, USA). Informed consent was obtained from all the parents. The statistical analyses were calculated using Student's $t$ test. 
Table 1 Birthweight, haematological status, FEP, and SF values at birth in 63 healthy low birthweight infants and in 21 healthy term infants. Mean value $( \pm S E)$. Only statistically significant differences are noted

\begin{tabular}{|c|c|c|c|c|c|c|}
\hline Group & $\begin{array}{l}\text { Birthweight } \\
(g)\end{array}$ & $\begin{array}{l}\text { Haemoglobin } \\
(g / d l)\end{array}$ & $\begin{array}{l}M C V \\
(f l)\end{array}$ & $\begin{array}{l}\text { Reticulocytes } \\
(\%)\end{array}$ & $\begin{array}{l}F E P \\
(\mu g / 100 \mathrm{ml} R B C)\end{array}$ & $\begin{array}{l}S F \\
(n g / m l)\end{array}$ \\
\hline $\begin{array}{l}\text { A }(n=63) \\
\text { A1 }(n=47) \\
\text { A2 }(n=16) \\
\text { Controls }(n=21)\end{array}$ & $\begin{array}{l}2140(35) \\
2275(21) \\
1740(55) \\
3330(86)\end{array}$ & $\begin{array}{l}20.1(0.35) \\
20.4(0.40) \\
19.2(0.67) \\
19.7(0.32)\end{array}$ & $\begin{array}{l}106(0 \cdot 7) \\
106(0 \cdot 9) \\
108(1 \cdot 1) \\
102(1 \cdot 0)\end{array}$ & $\begin{array}{l}2.6(0.2) \\
2.7(0.2) \\
2.5(0.4) \\
-\quad\end{array}$ & $\begin{array}{l}152(10 \cdot 2)^{\mathrm{a}} \\
148(12 \cdot 4) \\
178(16 \cdot 5)^{\mathrm{b}} \\
111(9 \cdot 3)\end{array}$ & $\begin{array}{l}226(17 \cdot 3) \\
236(22 \cdot 4) \\
179(15 \cdot 7)^{c} \\
281(25 \cdot 9)\end{array}$ \\
\hline
\end{tabular}

$\mathrm{MCV}=$ mean corpuscular volume.

aSignificantly higher $(P<0.02)$ than that of term infants, bsignificantly higher $(P<0.005)$ than that of term infants, ${ }^{c}$ significantly lower $(P<0.005)$ than that of term infants.

Table 2 Weight, haematological status, FEP, and SF values at ages 8-10 weeks in 44 healthy low birthweight infants. Mean value $( \pm S E)$

\begin{tabular}{lllllll}
\hline Group & $\begin{array}{l}\text { Weight } \\
(g)\end{array}$ & $\begin{array}{l}\text { Haemoglobin } \\
(\mathrm{g} / \mathrm{dl})\end{array}$ & $\begin{array}{l}M C V \\
(f)\end{array}$ & $\begin{array}{l}\text { Reticulocytes } \\
(\%)\end{array}$ & $\begin{array}{l}\text { FEP } \\
(\mu \mathrm{g} / 100 \mathrm{ml} R \mathrm{RBC})\end{array}$ & $\begin{array}{l}S F \\
(\mathrm{ng} / \mathrm{ml})\end{array}$ \\
\hline A $(\mathrm{n}=44)$ & $3530(105)$ & $10 \cdot 8(0 \cdot 18)$ & $90(0 \cdot 8)$ & $2 \cdot 1(0 \cdot 1)$ & $128(11 \cdot 9)$ & $107(11 \cdot 9)$ \\
A1 $(\mathrm{n}=32)$ & $3830(84)$ & $11 \cdot 1(0 \cdot 21)$ & $91(1 \cdot 0)$ & $2 \cdot 0(0 \cdot 1)$ & $125(14 \cdot 0)$ & $115(16 \cdot 6)$ \\
A2 $(\mathrm{n}=12)$ & $2730(157)$ & $10 \cdot 0(0 \cdot 26)$ & $88(1 \cdot 2)$ & $2 \cdot 5(0 \cdot 2)$ & $135(23 \cdot 9)$ & $87(12 \cdot 7)$ \\
\hline
\end{tabular}

Table 3 Weight, gestational age, Hb, FEP, and SF values at birth in 34 preterm appropriate for gestational age infants compared with 29 small for gestational age infants. Mean value $( \pm S E)$

\begin{tabular}{llllll}
\hline Group & $\begin{array}{l}\text { Gestational } \\
\text { age }(\text { weeks) }\end{array}$ & $\begin{array}{l}\text { Weight } \\
(\mathrm{g})\end{array}$ & $\begin{array}{l}\text { Haemoglobin } \\
(\mathrm{g} / \mathrm{dl})\end{array}$ & $\begin{array}{l}\text { FEP } \\
(\mu \mathrm{g} / 100 \mathrm{ml} \boldsymbol{R B C})\end{array}$ & $\begin{array}{l}S F \\
(\mathrm{ng} / \mathrm{ml})\end{array}$ \\
\hline AGA $(\mathrm{n}=34)$ & $30-36 \frac{1}{2}$ & $2125(53)$ & $19 \cdot 3(0 \cdot 42)$ & $142(12 \cdot 8)$ & $208(14 \cdot 9)$ \\
SGA (n=29) & $37-41$ & $2153(48)$ & $21 \cdot 1(0 \cdot 53)$ & $170(15 \cdot 2)$ & $248(33 \cdot 2)$ \\
\hline
\end{tabular}

$\mathrm{AGA}=$ appropriate for gestational age, $\mathrm{SGA}=$ small for gestational age.

*Range.

\section{Results}

Data on blood at birth are given in Table 1 and on blood at age 8-10 weeks in Table 2. Haemoglobin concentrations, reticulocyte counts, and mean corpuscular volumes were normal for age and birthweight. ${ }^{17-19}$ However mean FEP values were raised at 3-7 days, particularly in infants of low birthweight in whom they were $152 \mu \mathrm{g} / 100 \mathrm{ml}$ RBC. In term infants FEP values were $111 \mu \mathrm{g} / 100 \mathrm{ml}$ RBC. The difference was even more significant for the low birthweight infants (group A2) in whom they were $178 \mu \mathrm{g} / 100 \mathrm{ml} \mathrm{RBC} ; \mathrm{P}<0.005$. By age 8-10 weeks the mean FEP concentration in low birthweight infants was lower than at birth, but nevertheless it was still high.

SF values were high too in relation to birthweight both at 3-7 days and 8-10 weeks. During the first week of life group A2 infants had a mean SF concentration of $179 \mathrm{ng} / \mathrm{ml}$ compared with group A1 infants in whom it was $236 \mathrm{ng} / \mathrm{ml}$, and significantly lower than that of term infants in whom it was $281 \mathrm{ng} / \mathrm{ml} ; \mathrm{P}<0.005$.

At 8-10 weeks of life SF values were still raised, even in infants with birthweights $\leq 2000 \mathrm{~g}$. Although the mean SF value observed in group A2 infants was lower than that of group A1 infants, the difference was not statistically significant.

Neonatal FEP and SF values were related more closely to birthweight than gestational age. No significant differences were found between preterm low birthweight babies and those small for dates (Table 3).

\section{Discussion}

Micromeasurement of the FEP is now widely used to detect lead poisoning ${ }^{5-7}$ and to diagnose iron deficiency. ${ }^{2-4}$ The greatest increase in FEP level is present in lead overload, while in iron deficiency concentrations below $500 \mu \mathrm{g} / 100 \mathrm{ml} \mathrm{RBC}$ are found. ${ }^{20}$ In advanced iron deficiency anaemia, FEP values may be even higher. ${ }^{4}$ In normal children aged between 1 and 6 years, FEP values do not exceed $120 \mu \mathrm{g} / 100 \mathrm{ml}$ RBC. ${ }^{21}$

The SF assay also requires a small volume of serum or plasma, which may be obtained from capillary samples. ${ }^{22}$ At birth SF values are particularly high owing to fairly large iron stores ${ }^{11}$ (and, perhaps, to the additional mein.:.rsment of carcino-fetal isoferritins ${ }^{22}$ ). 
In the first weeks of life iron from senescent RBC accumulates in stores ${ }^{112324}$ during the development of hyporegenerative anaemia, which in the preterm infant results in minimum values at age 2 months. ${ }^{18}$ This stored iron is then utilised as soon as active erythropoiesis resumes. ${ }^{14} \mathrm{SF}$ values fluctuate in response to fluctuations in iron stores until age 6 months when the values stabilise. In infants and children aged between 6 months and 15 years, the normal SF range is 7 to $142 \mathrm{ng} / \mathrm{ml} .{ }^{11} \mathrm{SF}$ values below $7 \mathrm{ng} / \mathrm{ml}$ are present only in iron deficiency. ${ }^{1}$

In a previous study ${ }^{21}$ high neonatal FEP levels were found. There was no relationship between blood lead or haematocrit and increase in FEP. In contrast, serum iron values and transferrin saturation in infants with high FEP levels were significantly lower than those of normal infants. Thus it was suggested that a state of relative iron deficiency existed at birth. Nevertheless, no significant difference in SF values was found. These data however are scanty and need to be confirmed.

In the present study we have investigated FEP and SF values in a group of low birthweight infants during periods of stimulated erythropoiesis as shown by increased reticulocyte counts: at birth, when high fetal erythropoietic rate, although declining, is still present, and at age 2 months, when postnatal red cell production is resuming. Besides confirming raised FEP levels at birth, particularly in low birthweight infants, ${ }^{21}$ our findings showed high FEP values at 8-10 weeks. SF values taken at the same ages were also high and were similar to those of other reported series.11 14172324 In our babies a depletion of iron stores had been excluded.

As it had not earlier been investigated, we tried to find if a relationship existed between FEP and SF in infants of low birthweight at birth and at age 2 months. In fact, these two indices of iron metabolism are now regarded as the most practical and comprehensive tools in the estimation of iron deficiency, ${ }^{1}$ and are generally related to each other. ${ }^{3}{ }^{4}$ However in low birthweight infants we did not find any such correlation. This may be explained by the fact that SF reflects the iron stores whereas FEP values are more closely related to the dynamic balance between the iron supply and the demand of the erythron. ${ }^{34}$ Thus, it is possible that in low birthweight infants residual iron stores are still present at age 2 months, as shown by the presence of stainable iron in bone marrow aspirates ${ }^{25}$ and by SF values. Nevertheless the coexistence of high FEP values seems to support Lundström's hypothesis ${ }^{23}$ that in infants of low birthweight the rate of iron release from the stores may not be sufficient to maintain optimal erythropoiesis when the demand is increased.

Consequently, from a clinical point of view, even if there is no quantitative lack of iron storage, in low birthweight infants at age 2 months, deficient erythropoiesis, as raised FEP values show, is possible at this age and thus early iron supplementation is needed.

\section{References}

1 Dallman P R. New approaches to screenıng for iron deficiency. J Pediatr 1977; 90: 678-81.

2 Piomelli S, Brickman A, Carlos E. Rapid diagnosis of iron deficiency by measurement of free erythrocyte porphyrins and hemoglobin: the FEP/hemoglobin ratio. Pediatrics 1976; 57: 136-41.

3 Thomas W J, Koenig H M, Lightsey A L, Jr, Green R. Free erythrocyte porphyrin: hemoglobin ratios, serum ferritin, and transferrin saturation levels during treatment of infants with iron-deficiency anemia. Blood 1977; 49: 455-62.

4 Koller M E, Romslo I, Finne P H, Brockmeier F, Tyssebotn I. The diagnosis of iron deficiency by erythrocyte protoporphyrin and serum ferritin analyses. Acta Paediatr Scand 1978; 67: 361-6.

5 Piomelli S, Davidow B. Free erythrocyte protoporphyrin concentration: a promising screening test for lead poisoning (abstract). Pediatr Res 1972; 6: 366.

6 Piomelli S, Davidow B, Guinee V F, Young P, Gay G. The FEP (free erythrocyte porphyrins) test: a screening micro-method for lead poisoning. Pediatrics 1973; 51: 254-9.

7 Chisolm J J, Jr, Mellits E D, Keil J E, Barrett M B. A simple protoporphyrin assay-microhematocrit procedure as a screening technique for increased lead absorption in young children. $J$ Pediatr 1974 ; 84: 490-6.

8 Jacobs A, Miller F, Worwood M, Beamish M R, Wardrop C A. Ferritin in the serum of normal subjects and patients with iron deficiency and iron overload. Br Med J 1972; iv: 206-8.

9 Walters G O, Miller F M, Worwood M. Serum ferritin concentration and iron stores in normal subjects. $J$ Clin Pathol 1973; 26: 770-2.

10 Jacobs A, Worwood M. Ferritin in serum: clinical and biochemical implications. N Engl J Med 1975; 292: 951-3.

11 Siimes M A, Addiego J E, Jr, Dallman P R. Ferritin in serum: diagnosis of iron deficiency and iron overload in infants and children. Blood $1974 ; 43$ : 581-90.

12 Saarinen U M, Siimes M A. Serum ferritin in assessment of iron nutrition in healthy infants. Acta Paediatr Scand 1978; 67: 745-51.

13 Lanzkovsky O. Iron metabolism in the newborn infant. Clin Endocrinol Metab 1976; 5: 149-54.

14 Lundström U, Siimes M A, Dallman P R. At what age does iron supplementation become necessary in lowbirth-weight infants? J Pediatr 1977; 91: 878-83.

15 American Academy of Pediatrics Committee on Nutrition. Vitamin and mineral supplement needs in normal children in the United States. Pediatrics 1980; 66: 1015-21.

16 Piomelli S. A micromethod for free erythrocyte porphyrins: the FEP test. J Lab Clin Med 1973; 81: 932-40.

17 Jansson L, Holmberg L, Ekman R. Medicinal iron to low birth weight infants. Acta Paediatr Scand 1979; 68: 705-8.

18 Lundström U, Siimes M A. Red blood cell values in low-birth-weight infants: ages at which values become equivalent to those of term infants. $J$ Pediatr 1980; 96: 1040-2.

19 Oski F A. Hematologic disorders of fetus and newborn. 
The erythrocyte and its disorders. In: Nathan D G, Oski F A, eds. Hematology of infancy and childhood, second edition. Philadelphia: Saunders, 1981 : 17-49.

20 Langer E E, Haining $R$ G, Labbe $R$ F, Jacobs $P$, Crosby E F, Finch C A. Erythrocyte protoporphyrin. Blood 1972; 40: 112-8.

21 Gottuso M A, Oski B F, Oski F A. Free erythrocyte porphyrins in cord blood. J Pediatr 1978; 92: 810-2.

22 Segall M L, Heese $\mathbf{H}$ de V, Dempster W S. Estimation of serum ferritin in blood obtained by heelstick. $J$ Pediatr 1979; 95: 65-7.

23 Lundström U. Iron release from the stores: a mechanism in maintenance of concentration of hemoglobin in low-birth-weight infants. Acta Paediatr Scand 1980; 69: 249-52.
24 Haga P. Plasma ferritin concentrations in preterm infants in cord blood and during the early anaemia of prematurity. Acta Paediatr Scand 1980; 69: 637-41.

25 Seip M. Halvorsen S. Erythrocyte production and iron stores in premature infants during the first months of life. Acta Paediatr 1956; 45: 600-17.

Correspondence to Dr G Faldella, Istituto Clinico di Puericultura Università di Bologna, via Massarenti 11, 40138 Bologna, Italy.

Received 30 November 1982

Referees (continued from page 215)

$\begin{array}{lll}\text { J S Lilleyman } & \text { A M K Rickwood } & \text { C E Stroud } \\ \text { J M Littlewood } & \text { N R C Roberton } & \text { L S Taitz } \\ \text { J K Lloyd } & \text { A Robinson } & \text { J M Tanner } \\ \text { J Lorber } & \text { R J Robinson } & \text { M S Tanner } \\ \text { A Lucas } & \text { R O Robinson } & \text { M J Tarlow } \\ \text { N McIntosh } & \text { E MacD Ross } & \text { B Taylor } \\ \text { S McKenzie } & \text { G W Rylance } & \text { J F N Taylor } \\ \text { A S McNeish } & \text { I B Sardharwalla } & \text { D Thomas } \\ \text { M Mearns } & \text { J K Sarsfield } & \text { J H Tripp } \\ \text { D H Mellor } & \text { D C L Savage } & \text { T L Turner } \\ \text { C Metreweli } & \text { J W Scopes } & \text { W S Uttley } \\ \text { V Miller } & \text { G Scott } & \text { J A Walker-Smith } \\ \text { A D Milner } & \text { O Scott } & \text { J M Walshe } \\ \text { R D G Milner } & \text { N S Shah } & \text { P Watkins } \\ \text { R G Mitchell } & \text { D G Shaw } & \text { J G Watson } \\ \text { C B Modell } & \text { J C L Shaw } & \text { D Webster } \\ \text { P H Morris Jones } & \text { J R Sibert } & \text { R J West } \\ \text { A P Mowat } & \text { M Silverman } & \text { B A Wharton } \\ \text { R Newcombe } & \text { H Simpson } & \text { R H Whitaker } \\ \text { R E Olver } & \text { L Sinclair } & \text { R H R White } \\ \text { J M Parkin } & \text { J Smellie } & \text { A Whitelaw } \\ \text { A D Patrick } & \text { H Smith } & \text { J S Wigglesworth } \\ \text { R G Pearse } & \text { J W G Smith } & \text { A R Wilkinson } \\ \text { M Pembrey } & \text { R W Smithells } & \text { M L N Willoughby } \\ \text { M A Preece } & \text { B D Speidel } & \text { G B Winter } \\ \text { D A Price } & \text { L Spitz } & \text { R Winter } \\ \text { J F Price } & \text { T E Stacey } & \text { B S B Wood } \\ \text { J Pritchard } & \text { T C B Stamp } & \text { C B S Wood } \\ \text { P H W Rayner } & \text { J Stevenson } & \text { S R Yeates } \\ \text { G Richards } & \text { A L Stewart } & \text { D G Young } \\ \text { N S Richman } & \text { L Stimmler } & \text { W Yule } \\ \text { S } & & \end{array}$

